\title{
Enabling translanguaging in the French language classroom:
} Bridging the gap between multilingual perspectives and multilingual practice

\author{
Noella Charbonneau and Michiko Weinmann \\ ncharb@deakin.edu.au \\ DEAKIN UNIVERSITY
}

\begin{abstract}
Recent studies in multilingual and translanguaging pedagogies have shifted the focus from investigating how students engage their multilingual repertoires to exploring how teachers understand and implement these pedagogical directions in their practice. In this article, the authors report on a national online survey on the multilingual perspectives and practices of teachers of French in Australia. The overall goal of the survey discussed here was to comprehensively capture how teachers of French understand the teaching and learning of languages in general, and of French in particular. The study revealed several tensions between the language teachers' beliefs and practice. While most of the survey participants expressed strong support for innovative pedagogies such as translanguaging (García \& Wei, 2014), and keen motivation to engage the full multilingual repertoire of their learners, a closer reading of the data indicated that most of them felt restricted in their practice by "the normative terms and conditions of an understanding of languages education that remains rooted in parochial, monolingual and pecuniary perspectives" (Weinmann \& Arber, 2017, p. 173). In particular, the findings indicate that (self-)perceptions of "non-native" language teachers as "culturally deficient" continue to frame the notion of what constitutes a "good" language teacher (Holliday, 2015). For teachers to feel more confident and better equipped to effectively implement translanguaging pedagogies in their practice, teachers' perceptions of their own multilingual identities and how these are shaped within the systems they work in (Young, 2017) need to be better understood.
\end{abstract}

Key words: Languages teaching, languages education, translanguaging, native language teacher, non-native language teacher, linguistic repertoire, multilingualism, Australia 


\begin{abstract}
Résumé
Les débats récents concernant les pédagogies multilingues et de translanguaging sont de plus en plus axés non pas sur la manière dont les étudiants utilisent leurs répertoires multilingues, mais plutôt sur la manière dont les enseignants comprennent ces «nouvelles » orientations pédagogiques et leurs mises en application. Dans cet article, les auteures présentent une enquête en ligne sur les perspectives et les pratiques multilingues des enseignants de français en Australie. L'objectif de l'enquête, dont il est question dans cet article, était d'appréhender comment les enseignants de français comprennent l'enseignement et l'apprentissage des langues en général et du français en particulier. L'étude a révélé des tensions entre la pratique et les convictions des enseignants de langues. Alors que la plupart des participants à l'enquête ont exprimé leur soutien à des pédagogies innovantes telles que le translanguaging (García et Wei, 2014) et un intérêt à utiliser le repertoire multilingue de leurs apprenants, une lecture plus attentive des données indiquait que de nombreux enseignants se sentaient limités dans leur pratique par «les termes et conditions normatifs d'une compréhension des langues et de l'éducation aux langues qui reste ancrées dans des perspectives étroites, monolingues et pécuniaires » (Weinmann et Arber, 2017, p. 173). Les résultats indiquent en particulier que l'(auto) perception des enseignants non-natifs comme «culturellement déficients » continue de définir la notion de «bon » enseignant (Holliday, 2015). Pour que les enseignants se sentent plus en confiance et mieux équipés pour mettre en oeuvre efficacement les pédagogies du translanguaging, la perception des enseignants, de leur propre identité multilingue et de la manière dont ils s'inscrivent dans les systèmes dans lesquels ils travaillent (Young, 2017) doit être mieux comprise.
\end{abstract}

Mots-clés : Enseignement des langues, éducation, translanguaging, enseignant de langue native, enseignant de langue non-native, répertoire linguistique, multilingualisme, Australie

\title{
Introduction
}

Recent debates in multilingual and translanguaging pedagogies have increasingly shifted the focus from investigating how students engage their multilingual repertoires inside and outside the language classroom to exploring how teachers understand, respond to, and implement these pedagogical directions (Menken, 2008; Menken \& García, 2010). Theories of translanguaging and multilingualism give new horizons to both teacher practice and research in languages education by providing more flexible and inclusive perspectives of language and identity: "translanguaging for learners is a way to become more knowledgeable as language practices are expanded, for teachers, ... it becomes a pedagogy to educate children holistically, but also to teach all the students in 
the classroom" (García \& Wei, 2014, p. 89). Situated within the broader discussions around multilingualism and multilingual education, translanguaging expands the debate by emphasising the fluidity of languaging of multilingual speakers, and the intricacies of multilingual identities which are embodied, hybrid, relational, and constantly shifting: "translanguaging offers a way of capturing the expanded complex practices of speakers who could not avoid having had languages inscribed in their body, and yet live between different societal and semiotic contexts as they interact with a complex array of speakers" (p. 18). As an emerging multilingual pedagogy, translanguaging strives to overcome "systems that have been described as separate ... [to] create[s] changes in inter-active cognitive and social structures" (p. 42), thus opening up opportunities in classrooms for shifting conventional understandings of what constitutes a multilingual "linguistic repertoire" and for exploring and utilising all students' language resources more comprehensively.

Numerous studies have identified that conventional understandings of bilingualism and multilingualism persist even in highly linguistically and culturally diverse societies such as Australia (Piller, 2016; Vertovec 2007), and continue to shape the identities and practices of language teachers (D'warte, 2018; Turner \& Cross, 2016; Weinmann \& Arber, 2017). However, the studies emphasize that teacher practice has the potential to contribute to more comprehensive multilingual perspectives, experiences, and encounters by shifting the ways in which languages are taught and learnt (Canagarajah, 2008; Flores \& Schissel, 2014; Swain \& Lapkin, 2005). Despite this, to date only a small body of research explores languages teachers' perspectives and beliefs on multilingualism and multilingual pedagogies (De Angelis, 2011; Pulinx, Van Avermaet, \& Agirdag, 2017; Van Der Walt \& Klapwijk, 2015; Young, 2014). Van Der Wildt, Van Houtte, and Van Avermaet (2017) advocate for more qualitative studies in this area, arguing that such research could provide more complex insights into "the interaction between individual teachers' monolingual beliefs and their teaching practices, and how school policies or innovative implementation programs influence these" (p. 148). This study is part of a reconstitution within the field to interrogate and reorient the normative terms and conditions that shape the teaching and learning of languages. The authors argue that for teachers to feel more confident and better equipped to effectively implement multilingual pedagogies such as translanguaging in their practice, teachers' perceptions of their own multilingual identities and how these are shaped within the systems they work in (Young, 2017) need to be better understood.

\section{Traversing linguistic diversity and the monolingual mindset}

The national context in which this study is located has historically been characterized by the considerable linguistic diversity of Aboriginal and Torres Strait 
Islander societies and cultures. Over the last two hundred years, Australia's unique linguistic landscape has become further diversified through migration from around the world (Baker, 2011; Dudgeon, Wright, Paradies, \& Walker, 2010; Rumsey, 2018). The last census identified 300 languages spoken in Australia with more than one-fifth $(21 \%)$ of the population speaking a language in addition to English at home. While Aboriginal and Torres Strait Islander peoples represent only $2.8 \%$ of the total population, census data reported that 150 Australian Indigenous languages are spoken at home (Australian Bureau of Statistics, 2016).

However, Australia's language potential is juxtaposed by a "monolingual mindset" (Clyne, 2005; Hajek \& Slaughter, 2015), encouraging monolingual ideologies of a hegemonic English language over other languages (Truscott \& Malcolm, 2010). A pervasive deficit view of multilingualism is reflected by:

- a succession of failures of national language policies and languages education targets (Liddicoat, 2010; Lo Bianco \& Aliani, 2013)

- the recent count of 216 dead or dying languages in Australia and New Zealand (Simons \& Lewis, 2013)

- re-emerging assimilation discourses underpinning changes in citizenship policy such as the provision of English languages courses for refugees and migrants, and a call for stricter English-language testing and proficiency requirements (Ndhlovu, 2018)

Scholarly debate in Australia has long been advocating for explorations of how heteroglossic approaches could open up new spaces for (languages) education that take "advantage of the increasingly multilingual composition of language classes and ... draw on the students' multilingual competences" (Kramsch, 2012, p. 1). It is argued that the diversity of communities are resources that education policies and systems need to integrate more comprehensively so that "multilingual identities and competences can be valued in schools. ... Multilingualism can serve to construct a sense of belonging to one or more groups, and ... through multilingualism, social cohesion and justice for all can be promoted" (Conteh \& Meier, 2014, p. 1). Teachers - and in particular languages teachers - have been identified as central entities in the creation and facilitation of such "heteroglossic spaces" (Flores \& Schissel, 2014) that support students' use of their entire linguistic repertoire to enrich classroom interactions and to promote learning.

\section{The context of French language education in Australia}

Historically, the teaching and learning of the French language has always had an important place in Australia: 
French has been taught in Australian schools and universities since the 1880s.... As Asian languages joined European languages in school programs, numbers of students learning French declined, but French continues to be studied at all levels across all states and territories and is currently the third most widely studied language in schools. Wider community interest in learning French is strong, as evidenced by enrolments in courses offered by regional branches of the Alliance Française and the proliferation of informal community-based French conversation groups and language clubs. (ACARA, 2014, pp. 1-2)

However, the position of French as one of the most popular languages in Australian schools has to be considered within the broader context of enrolment numbers that continue to decline, particularly in the senior secondary years:

Language enrolment in Year 12 overall is dropping in Australia. "Only 8 per cent of the more than 75,000 students enrolled ... will sit a foreign language test ... down from more than 50 per cent in the 50 s. ... French remained the most popular language for school leavers in NSW [New South Wales; the state with the largest population in Australia], but enrolments in all of the top five most popular languages except Japanese fell in the past year. (Tovey \& McNeilage, 2013)

Despite these trends, engagement of the French government to promote French language and culture continues to be strong in Australia and is well represented through various initiatives that complement the French language programs offered in Australian schools across its government, independent, and Catholic sectors. The French Embassy in Australia has supported a variety of bilingual French-English education programs over many years; further, it initiated and governs the Australian Association of French English Bilingual Schools (AAFEBS). Currently, there are 14 bilingual schools throughout Australia, which employ 310 teachers and have a student enrolment of 3,500 (AAFEBS, 2018). The bilingual French programs in Australia are diverse and comprise three strands:

- schools following the Australian curriculum

- bi-national programs that draw on the national curricula for both France and Australia

- one school that teaches the French curriculum exclusively

The well-established prominence of French language education in Australia presents a dynamic context through which the nexus of Francophonie and multilingual education can be explored. The aim of the research from which this paper is drawn was to glean initial insights into the practice of teachers of French in Australia, the emerging tensions between their multilingual perspectives about teaching and practice, and the beliefs and views that shaped 
their understanding of the teaching and learning of French, and languages more generally.

\section{The study: Research design, methods, and methodology}

Our study reports on a recent national online survey (2016) of teachers of French across Australia. A call for participation and the weblink to the online survey was disseminated through three key bodies for the teaching and learning of French in Australia: the Alliances Françaises (Director-General of Alliance Française in Australia [DGAF]), professional French language teacher associations at both national and state and territory level, ${ }^{1}$ and the French bilingual school network (AAFEBS).

The survey included nine Likert-scale questions and ten open-ended questions. Adopting a socio-constructivist framework, the study aimed to explore the perspectives of teachers of French on multilingualism and multilingual pedagogies through their own language learning trajectories and their teaching practice. Major themes that were explored in the survey included perceptions of the connection between language, culture, and identity in languages teaching and learning; identity negotiation; teachers' understandings of multilingualism; teaching practice in multilingual and multicultural languages classrooms; and teachers' understandings of multilingual and translanguaging pedagogies.

The study engaged a mixed-method approach comprising both quantitative and qualitative methods of gathering and analysing data. An inductive approach was used to formulate emerging hypotheses about which understandings of language and multilingualism shaped teachers' practices and pedagogies. Subsequently, critical discourse analysis was engaged to identify the tropes and discourses underlying the participant teachers' perspectives on teaching and learning languages, especially French, both within the Australian context and globally.

Survey participants were adults aged 18 years or older, who taught in a wide range of French language programs in Australian preschool, primary, and secondary and adult education contexts. The participant population included 85 teachers of French, with $93 \%$ of the respondents being female. Most of the survey participants (66\%) were born overseas, with $42 \%$ of the respondents having been born in a French-speaking country. The majority of

\footnotetext{
${ }^{1}$ Federation of Associations of Teachers of French in Australia [FATFA]; French teachers' ACT network; New South Wales Association of French teachers [NAFT]; Queensland MLTAQ French branch; South Australian French Teachers Association [SAFTA]; Association of French Teachers in Victoria [AFTV]; Teachers of French Association in Western Australia [TOFA].
} 
respondents taught in secondary schools (60\%), and in "non-bilingual" schools (78\%). Two-thirds (66\%) of the population was over 40 years old. Most of the teachers had significant teaching experience as depicted in Figure 1. More than half of the population (54\%) had teaching experience of ten or more years, and more than a third of the participant population had taught for over 20 years.

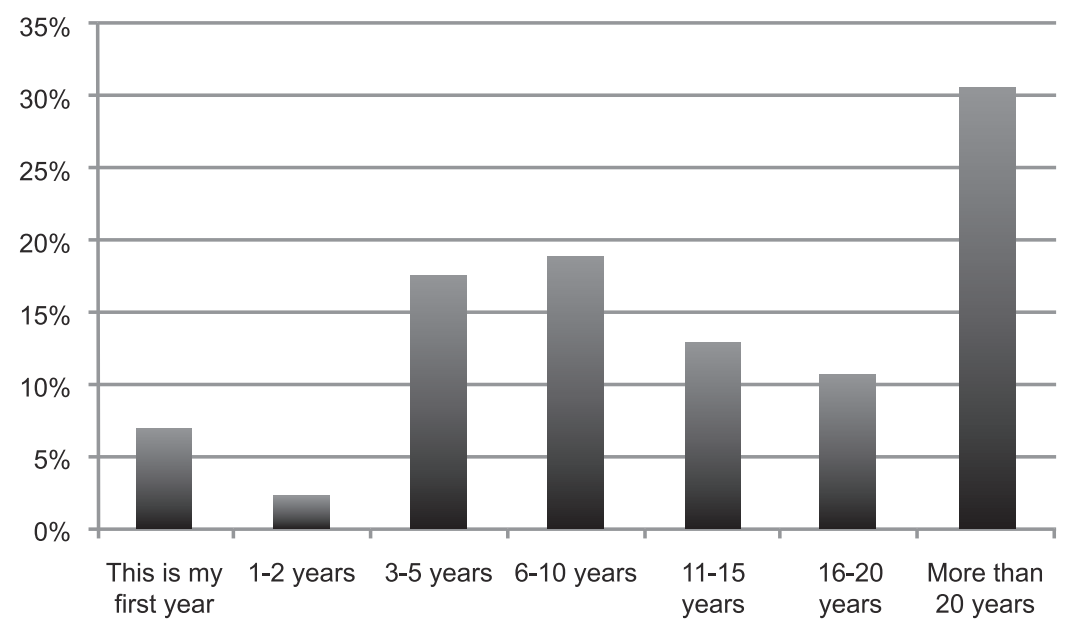

Figure 1

Participants' teaching experience (by percentage)

\section{Theoretical underpinnings}

Over recent decades, research exploring the nexus of language, culture, and identity has experienced a shift from monoglossic to heteroglossic frameworks. Building on the premise that languaging is a complex and dynamic process (Molyneux, Scull, \& Aliani, 2016; Otsuji \& Pennycook, 2016), the multilingual turn and associated recent literatures have brought to view the ways that multilingual speakers engage the resources of the different languages to which they have access (García \& Wei, 2014; May, 2013).

Research exploring languages teaching and learning continues to reconceptualize notions of language as a pre-existing entity (Makoni \& Pennycook, 2006) towards a fluid set of practices, "a form of action that emerges within particular social and cultural contexts" (Palmer \& Martínez, 2013, p. 276). However, the dynamics of multilingual practices are mediated by the rules and structures of institutions, and negotiated within the larger fields of social, economic, and cultural relations (Allard, 2017; Schissel, De Korne, \& López-Gopar, 2018). The power of education systems, and the far-reaching 
impact that schools and teachers play as intermediaries within a world articulated through language and culture has been widely acknowledged and debated (Kramsch \& Jessner, 2015). In particular, the pervasive opposition between societal multilingualism and the linguistic diversity in increasingly globalized classrooms, and the monolingual ideologies underpinning national education systems and policies (Gogolin, 1997; Shohamy, 2006) point to an ongoing disjunct that teachers have to navigate and make sense of in their everyday classroom practice.

Recent multilingual and translanguaging theories and frameworks give new horizons to languages education research and pedagogies by offering new approaches to respond to and engage with the multilingual contexts within and beyond classrooms: "translanguaging for learners is a way to become more knowledgeable as language practices are expanded, for teachers, ... it becomes a pedagogy to educate children holistically, but also to teach all the students in the classroom" (García \& Wei, 2014, p. 89). Studies on teachers' views about the multilingualism of the students in their classrooms (De Angelis, 2011; Moloney \& Xu, 2016) suggest that innovative pedagogies such as translanguaging could offer a powerful space for teachers to engage in their own multilingualism in a more complex manner. Such reflections encompass the potential to question, unveil, and disrupt engrained monoglossic practices towards the facilitation and implementation of comprehensive multilingual pedagogies in languages classrooms and beyond (Wei, 2017).

\section{Exploring multilingual perceptions and multilingual practice}

This article focuses on the qualitative responses of participants generated from the online survey. Through selected quotes from the French language teachers' comments and stories, their understandings of "language", and their multilingual trajectories, encounters, and practice are examined and interrogated.

\section{Supporting multilingual pedagogies}

Both quantitative and qualitative survey data indicate that most participants were aware of their students' linguistic and cultural diversity, and were committed to supporting and fully engaging the multilingual resources of their students in the languages classroom. Responses to the Likert-scale questions produced the following results:

- $90 \%$ of the survey participants agreed or strongly agreed that multilingualism is not an obstacle to learning French.

- $88 \%$ of the participant population believed that support of first language or home language enhances competence in the other languages. 
- Only $11 \%$ of participants found that code-switching is detrimental to students' language-learning progress.

- 79\% of survey participants agreed or strongly agreed that they require further professional learning to adapt their teaching to the significant growing proportion of multilingual students.

The above trend is reiterated in the qualitative responses provided:

In the UK, I had a lot of Urdu speakers ... it helps them to explain to each other in their own language.

I try to adapt my teaching when I have children who are already bilingual in other languages to take into account their linguistic background.

Students' backgrounds provide a wealth of resources in learning additional languages - students can compare and contrast, and it makes the learning relevant to the students' lived experiences.

In the statements quoted, the teachers acknowledge the importance of creating an ecology in their classrooms that affirms students' language practices, while providing authentic opportunities for them to adapt new pedagogical practices that draw on the students' full linguistic repertoire (García \& Menken, 2015). Furthermore, these participant quotes reveal that teachers are well aware of the increasingly multilingual context of their classrooms, and are proactive in adapting their practice and pedagogy to create opportunities for students to use their full linguistic repertoire for their learning. The different ways of understanding and being in the world that multilingual and multicultural students bring to the classroom are acknowledged as important resources to support learning.

However, other responses expressed concern around the diversity the French language teachers experienced in their classrooms, and the implications of this for their practice:

The number of languages spoken at home is so diverse that I cannot claim to be qualified enough to cater for each student's linguistic and cultural background.

I teach over 300 students per week. It is hard to keep track of ... which language they speak at home.

These quotes suggest a misconception that individualized teaching means catering for every single student in a different way and, further, that it requires in-depth knowledge of every single language and culture represented in the classroom. It should be noted that this was a common concern, which was expressed in several responses. An interesting observation that can be derived from these responses is a disconnect in teachers' confidence to engage with linguistic diversity in the French language classroom, and an awareness of the 
limitations in their knowledge of the languages and cultures represented by the students they taught, and confusion over how to utilize their students' multilingual resources effectively and equitably in teaching and learning.

\section{Languages as a resource in theory and practice}

A closer look at the qualitative responses presents a different perspective to stances expressed earlier. When prompted to comment in more detail about how they implement multilingual pedagogies in their classrooms, some of the teacher responses suggested an understanding of languages that continued to see them as fixed, and geographically and nationally determined. In particular, when teachers discussed the relationship of other languages relative to French, the ways in which they spoke of different languages points toward a differentiation in the usefulness and relevance of languages, whereby some languages were seen as more useful and relevant than others:

If it is a European language, it helps ... but I am not sure how other languages can help except by developing "an ear". I don't think for example that Asian language structures help with French grammar at all!

It depends on the language, as some languages are so very different [that] the linguistic assistance is minimal. Roman languages can help them understand French language and culture, as they have on common root language (Latin). Some French words are used in English, so English is useful too. I am not sure about other languages.

There are several observations to be made about these quotes. Firstly, languages are classified within binary categories of Asian and European languages. Languages are also seen as predominantly linguistic entities, which in the quoted comment are considered as self-contained and separate systems of language structures independent of the speakers, their identities, and the spaces they inhabit. This is in opposition to the perceptions expressed in the preceding section, which articulate an understanding that sees languaging as "the simultaneous process of continuous becoming of ourselves and of our language practices, as we interact and make meaning in the world" (García \& Wei, 2014, p. 8).

The statements discussed so far highlight the complexities of navigating the theoretical understanding of the value of multilingual pedagogies, and the practicalities of their implementation. It involves constant renegotiation, and requires continued interrogations of acquired monoglossic beliefs and languages pedagogies, which continue to reinforce rather than overcome representations of linguistic dominance in the languages classroom (Canagarajah \& Ashraf, 2013). 


\section{Teachers' self-doubts about their linguistic and cultural expertise}

A substantive body of research has demonstrated that teachers' identities shape their practice and the pedagogies they use in the classroom (Cheung, Said, \& Park, 2015; De Costa \& Norton, 2017; Kanno \& Stuart, 2011; Morgan \& Clarke, 2011). A finding that warrants emphasis is that languages teachers are often inclined to apply a deficit view to their own multilingualism and to the multilingual competency of others:

I have never been to France, but studied French all through high school and one year at university, and have taught it at various stages of my career. I am aware of my weaknesses, so try to find out as much as I can in order to pass it on to students.

I do not fully know how it must be for non-bilingual or bicultural teachers to understand how to teach French when they themselves have only experienced one culture. Personally, my belief is that any bicultural person would be more competent as they would understand many aspects of [cultural] diversity, what that means and how to nurture and embrace this.

These comments display a common narrative about a perceived lack of adequate skills to teach one's "non-native" language. Moreover, binaries rooted in notions of nation and nativity continue to shape these respondents' perceptions of a hierarchy in teacher "quality", which prefers "native" over "nonnative" speaker teachers (Kramsch, 2016). These binaries align with the assumption of a language hierarchy among the languages spoken by students and teachers that was identified earlier. Such perceptions are highly pervasive, despite compelling research evidence that "native" speaker proficiency does not equal competency in linguistic and cultural knowledge, understanding, and effective teaching practice:

Many school systems prefer to hire native speakers as language teachers because of their authentic relationship to the target language and culture, but native speakers don't necessarily know the home culture of their students nor the intellectual tradition of their school system. (Kramsch, 2013, p. 59)

Literatures of multilingual pedagogies emphasize the need to support all languages teachers to shift the focus from perceived deficit views of their multilingual expertise towards "intercultural perspectives" of teaching - that is, "the ways teachers understand the diversity of languages and cultures, their lives within this diversity and its relationship to their work as teachers" (Liddicoat \& Scarino, 2013, p. 16). The transformative direction of emerging pedagogies such as translanguaging advocate for the opening up of spaces enabling diverse linguistic, cultural, and cognitive engagement and learning for students. These principles could also be applied to engage languages teachers in reflections towards a more empowering and empowered multilingual stance 
acknowledging that "being a 'native speaker' has nothing whatever to do with the abilities to be a teacher of a particular language" (Holliday, 2015, p. 16).

\section{Systemic trajectories and challenges}

While this article can only present a limited snapshot of illustrations of how French language teachers in Australia navigated their multilingual beliefs, perceptions, and the implementation of multilingual and translanguaging pedagogies, the emergent theme of a complex tension between innovative perspectives and practices - and the limitations teachers experienced in implementing these - warrants particular attention. The narrative survey comments highlight that teachers articulated their multilingual beliefs and positions differently when they discussed them as theoretical constructs on one hand, and pedagogical practice on the other hand. The survey data align with findings from previous studies that point out that tensions in navigating multilingual perceptions and practice become apparent in languages classroom environments where identities are constructed and negotiated by both students and teachers (Norton 2000, 2006, 2010, 2013, 2016; Norton \& Toohey, 2002, 2011). It is in classroom contexts where "fragmented, decentered, and shifting" (Pavlenko $\&$ Blackledge, 2004, p. 18) identities are juxtaposed with systemic constraints, that the teachers' capacity to move beyond ideological and structural boundaries towards an effective implementation of their multilingual practice is significantly curtailed.

Moreover, teacher practice is shaped by teachers' experiences of their own education, the expectations of what languages teaching involves, and the particular objectives of languages programs in their teaching context. This adds further complexity to the negotiation of the disjunct in teachers' multilingual perspectives and practice outlined earlier.

The following comments illustrate the tensions emerging from everyday challenges and pressures when teachers' understandings of the requirements of language, languages teaching and learning and education standards and systems pose a scenario of factors that is too complex to untangle:

I am stunned by the lack of grammatical knowledge even in their own language like English displayed by the students. It is NOT ACCEPTABLE [sic] to have to explain what an adverb is or a tense or a conjunction or a preposition at a senior level ... the system should do something about it at a junior level ... and their vocabulary level is not what it should be either at a certain level.

I believe that teaching bilingual or multilingual students is actually easier than teaching monolingual English students because bilingual students already have the neurological pathways ... and are generally more open to acquiring language ... . Therefore, I don't really believe that extra support is necessary for teaching bilingual students. Rather, extra focus needs to be given to increasing 
the amount of students studying languages at an earlier age so that they can become bilingual, rather than just learning a small amount once they reach high school.

In the first quote, shortcomings in the knowledge of grammar and vocabulary are seen as a result of the ongoing systemic failure of the Australian education system to adequately support the curriculum discipline of languages as well as cross-curricular language awareness, including foundational knowledge of grammar, structure, and genre (Lo Bianco \& Slaughter, 2017; Weinmann \& Arber, 2016). Further, the quote suggests a prioritisation of the teaching and learning of language structure which — taken together with the systemic shortcomings - pose significant hindrance to the implementation of more comprehensive multilingual pedagogies. As the second quote suggests, "monolingual English students" are considered in particular need of additional support to develop the foundations in a second language more comprehensively, and at an earlier stage in their schooling. While this statement emphasises the cognitive advantages that multilingual speakers bring to learning another language, it shifts the deficit view of multilingualism often applied to bilingual speakers to the monolingual speaker. This emphasises that binary categories of language speakers and learners are difficult to overcome when teachers have to ensure that learning outcomes of the curriculum are achieved.

I like to make the learning fun and focus on student engagement and work hard to try to balance all factors as much as possible. BUT [sic] being a private school, I feel the pressure ... of having to report and assess.

Unfortunately, in a secondary school setting, the focus is generally on assessments so that influences too much what I teach (as students need to be ready for assessments). There are also many interruptions to lessons in schools and this has an effect on what and how I teach. I try to ensure students have contact with real people who speak the languages I teach and use it in a meaningful way.

As the two above comments suggest, the well-documented pressures of assessment and reporting on teachers can have a far-reaching impact on the practice of languages teachers in Australia, where languages education continues to be considered of lesser importance than other disciplines. The juggling act of the implementation of innovative pedagogies that are responsive to the needs of all students, and the pressures to achieve and produce results and outcomes, often leave only limited space for discussions between teachers, curriculum and assessment bodies to rethink and shift current pedagogical practice (De Mejía \& Hélot, 2015; Hélot \& Ó Laoire, 2011; Young, 2014).

\section{Conclusion}

Our discussion has highlighted that the respondents to the online survey were well aware of the importance of the linguistic diversity in globalized contexts 
like Australia where English may be considered the national lingua franca, but where a "one state/one culture/one language" understanding fails to capture the multilingual condition of the country (Pérez-Milans, 2016, p. 87). Many of the qualitative comments also indicated that teachers appreciated that the classroom was a space where multilingual identities are constructed and negotiated by both students and teachers. The majority of responses showed that teachers were committed to implementing innovative and translanguaging pedagogies in order to respond more comprehensively to the globalized conditions in their French language classrooms:

The goals of traditional language teaching have been found wanting in this new era of globalisation. Its main tenets (monolingual native speakers, homogeneous national cultures, pure standard national languages, instrumental goals of education, functional criteria of success) have all become problematic in a world that is increasingly multilingual and multicultural. (Kramsch 2009, p. 190)

However, the study revealed significant tensions between language teachers' multilingual beliefs and practices. In particular, teachers' expressions of sentiments of lack of confidence in their own multilingual skills and their expertise around multilingual pedagogies suggested that they felt constrained by the pervasive monoglossic presuppositions that shape their understanding of languages education, and what it means to be a "good" French language teacher within the context of increasingly multilingual and globalized classrooms. Further, the experienced lack of systemic flexibility and a lack of adequate professional learning opportunities was seen as inhibiting the implementation of multilingual and translanguaging practices.

The majority of teachers who participated in the study acknowledged the multilingualism of their students as a valuable resource, but were quick to perceive their own multilingualism as limited. Innovative multilingual pedagogies like translanguaging follow on from the premise that teaching and learning is a languaged and "an intensely human activity" (Ebarvia, 2018, para. 2), especially in the languages classroom. As Ebarvia describes:

We bring ... our identities - and the experiences that informed them - into our teaching. So we have to interrogate the ways in which these experiences have shaped our practices ... (para. 3)

We teach who we are. This is what can make our practice so powerful - even transformative ... (para. 2)

But I would argue that it's often our personal identities and experiences ... which most often ... go unexamined. (para. 4)

Innovative multilingual approaches such as translanguaging could offer a more fluid and flexible understanding of language teaching and learning, encouraging more "freedom" and openness, not just for students, but also for 
teachers. This could open up a powerful space for teachers to engage in their own multilingual identities in a more complex and empowering manner. Releasing this currently under-appreciated potential of translanguaging pedagogies could have far-reaching benefits for both students and teachers of languages by encouraging a more fluid and flexible understanding of language and languaging in classrooms and staffrooms.

\section{References}

Allard, E.C. (2017). Re-examining teacher translanguaging: An ecological perspective. Bilingual Research Journal, 40, 116-130. doi.org/10.1080/15235882.2017.1306597

Australian Association of French English Bilingual Schools (AAFEBS). (2008). About [Website]. www.aafebs.com

Australian Bureau of Statistics (ABS). (2016). 2071.0 - Census of population and housing: Reflecting Australia-Stories from the census, 2016. Canberra: ABS. www.abs.gov.au/ausstats/abs@.nst/mf/2071.0

Australian Curriculum, Assessment and Reporting Authority (ACARA). (2014). Australian Curriculum: Languages - French (revised). Sydney, Australia: ACARA. docs.acara.edu.au/resources/F-10_Australian_Curriculum_Languages_French_(revised)_for_ public_viewing_-_February_2014_file.pdf

Baker, C. (2011). Foundations of bilingual education and bilingualism. Buffalo, NY: Multilingual Matters.

Canagarajah, A.S. (2008). Language shift and the family: Questions from the Sri Lankan Tamil diaspora. Journal of Sociolinguistics, 12(1), 1 ?34.

Canagarajah, S., \& Ashraf, H. (2013). Multilingualism and education in South Asia: Resolving policy/practice dilemmas. Annual Review of Applied Linguistics, 33, 258-285.

Cheung, Y.L., Said, S.B., \& Park, E. (Eds.). (2015). Advances and current trends in language teacher identity research. New York: Routledge/Taylor \& Francis.

Clyne, M. (2005). Australia's language potential. Sydney: University of New South Wales Press.

Conteh, J., \& Meier, G. (Eds.). (2014). The multilingual turn in languages education: Opportunities and challenges. Bristol, UK: Multilingual Matters.

De Angelis, G. (2011). Teachers' beliefs about the role of prior language knowledge in learning and how these influence teaching practices. International Journal of Multilingualism, 8, 216-234.

De Costa, P.I., \& Norton, B. (2017). Introduction: Identity, transdisciplinarity, and the good language teacher. Modern Language Journal, 101, 3-14.

De Mejía, A.M., \& Hélot, C. (2015). Teacher education and support. In W.E. Wright, S. Boun, \& O. García (Eds.), Handbook of bilingual and multilingual education (pp. 270-281). Malden, MA: John Wiley \& Sons. 
Dudgeon, P., Wright, M., Paradies, Y., Garvey, D., \& Walker, I. (2010). The social, cultural and historical context of Aboriginal and Torres Strait Islander Australians. Working together: Aboriginal and Torres Strait Islander mental health and wellbeing principles and practice (pp. 25-42). Canberra, Australia: Australian Institute of Health and Welfare.

D'warte, J. (2018). Recognizing and leveraging the bilingual meaning-making potential of young people aged six to eight years old in one Australian classroom. Journal of Early Childhood Literacy. doi.org/10.1177/1468798418769361

Ebarvia, T. (2018, July 27). We teach who we are: Unpacking our identities [Blog]. triciaebarvia.org/2018/07/27/we-teach-who-we-are-unpacking-our-identities

Flores, N., \& Schissel, J.L. (2014). Dynamic bilingualism as the norm: Envisioning a heteroglossic approach to standards-based reform. Tesol Quarterly, 48, 454-479.

García, O., \& Wei, L. (2014). Translanguaging: Language, bilingualism and education. Basingstoke, UK: Palgrave Macmillan.

García, O., \& Menken, K. (2015). Cultivating an ecology of multilingualism in schools. In B. Spolsky, O. Inbar-Lourie, \& M. Tannenbaum (Eds.), Challenges for language education and policy: Making space for people (pp. 95-108). New York: Routledge.

Gogolin, I. (1997). The "monolingual habitus" as the common feature in teaching in the language of the majority in different countries. Per Linguam, 13(2), 38-49.

Hajek, J., \& Slaughter, Y. (Eds.). (2015). Challenging the monolingual mindset. Bristol, UK: Multilingual Matters.

Hélot, C., \& Ó Laoire, M. (Eds.). (2011). Language policy for the multilingual classroom: Pedagogy of the possible. Clevedon, UK: Multilingual Matters.

Holliday, A. (2015). Native-speakerism: Taking the concept forward and achieving cultural belief. In A. Swan, P. Aboshiha, \& A. Holliday A. (Eds.), (En)Countering native-speakerism (pp. 11-25). London: Palgrave Macmillan. doi.org/10.1057/9781137463500_2

Kanno, Y., \& Stuart, C. (2011). The development of L2 teacher identity: Longitudinal case studies. Modern Language Journal, 95, 236-252.

Kramsch, C. (2009). The multilingual subject: What foreign language learners say about their experience and why it matters. Oxford, UK: Oxford University Press.

Kramsch, C. (2012). Authenticity and legitimacy in multilingual SLA. Critical Multilingualism Studies, 1, 107-128.

Kramsch, C. (2013). Culture in foreign language teaching. Iranian Journal of Language Teaching Research, 1, 57-78.

Kramsch, C. (2016). The multiple faces of symbolic power. Applied Linguistics Review, 7, 517-529. doi.org/10.1515/applirev-2016-0023 
Kramsch, C., \& Zhang, L. (2015). The legitimacy gap: Multilingual language teachers in an era of globalization. In U. Jessner (Series Ed.), Trends in Applied Linguistics: Vol. 16: U. Jessner \& C.J. Kramsch (Vol. Eds.), The multilingual challenge: Crossdisciplinary perspectives (pp. 87-114). Boston: Mouton de Gruyter.

Liddicoat, A. (2010). Policy change and educational inertia: Language policy and language education in Australian schooling. Newcastle upon Tyne, UK: Cambridge Scholars Publishing.

Liddicoat, A., \& Scarino, A. (2013). Intercultural language teaching and learning. Chichester. UK: Wiley-Blackwell.

Li Wei. (2017). Translanguaging as a practical theory of language. Applied Linguistics, 39, 9-30.

Lo Bianco, J., \& Aliani, R. (2013). Language planning and student experiences: Intention, rhetoric and implementation. Bristol, UK: Multilingual Matters.

Lo Bianco, J., \& Slaughter, Y. (2017). Language policy and education in Australia. In T. McCarty \& S. May (Eds.), Language policy and political issues in education (pp. 449-461). New York: Springer.

Makoni, S., \& Pennycook, A. (2006). Disinventing and reconstituting languages. Clevedon, UK: Multilingual Matters.

May, S. (Ed.). (2013). The multilingual turn: Implications for SLA, TESOL, and bilingual education. New York: Routledge.

Menken, K. (2008). English learners left behind: Standardized testing as language policy. Bristol, UK: Multilingual Matters.

Menken, K., \& García, O. (Eds.). (2010). Negotiating language policies in schools: Educators as policymakers. New York: Routledge.

Moloney, R., \& Xu, H.L. (2016). Exploring innovative pedagogy in the teaching and learning of Chinese as a foreign language. Singapore: Springer.

Molyneux, P., Scull, J., \& Aliani, R. (2016). Bilingual education in a community language: Lessons from a longitudinal study. Language and Education, 30, 337-360. doi.org/10.1080/09500782.2015.1114630

Morgan, B., \& Clarke, M. (2011). Identity in second language teaching and learning. In E. Hinkel (Ed.), Handbook of research in second language teaching and learning (Vol. 2, pp. 817-836). New York: Routledge/Taylor \& Francis.

Ndhlovu, F. (2018). Migration, integration discourse, exclusion. In F. Ndhlovu, Language, vernacular discourse and nationalisms: Uncovering the myths of transnational worlds (pp. 243-290). London: Palgrave Macmillan.

Norton, B. (2000). Identity and language learning: Gender, ethnicity and educational change. Harlow, UK: Longman.

Norton, B. (2006). Identity as a sociocultural construct in second language research. TESOL in Context [thematic issue: Tales out of school: Identity and English language teaching], Series $S, 22-33$. 
Norton, B. (2010). Language and identity. Sociolinguistics and Language Education, 23, 349-369.

Norton, B. (2013). Identity and language learning: Extending the conversation. Bristol, UK: Multilingual matters.

Norton, B. (2016). Identity and language learning: Back to the future. TESOL Quarterly, 2, 475-479. doi.org/10.1002/tesq.293

Norton, B., \& Toohey, K. (2002). Identity and language learning. In R. Kaplan (Ed.), The Oxford handbook of applied linguistics (pp. 115-123). Oxford: Oxford University Press.

Norton, B., \& Toohey, K. (2011). Identity, language learning, and social change. Language Teaching 44, 412-446.

Otsuji, E., \& Pennycook, A. (2016). Metrolingualism: Fixity, fluidity and language in flux. International Journal of Multilingualism, 7, 240-254.

Palmer, D., \& Martínez, R. A. (2013). Teacher agency in bilingual spaces: A fresh look at preparing teachers to educate Latina/o bilingual children. Review of Research in Education, 37, 269-297.

Pavlenko, A., \& Blackledge, A. (Eds.). (2004). Negotiation of identities in multilingual contexts. Bristol, UK: Multilingual Matters.

Pérez-Milans, M. (2016). Language and identity in linguistic ethnography. In S. Preece (Ed.), The Routledge handbook of language and identity (pp. 83-97). New York: Routledge.

Piller, I. (2016). Monolingual ways of seeing multilingualism. Journal of Multicultural Discourses, 11, 25-33.

Pulinx, R., Van Avermaet, P., \& Agirdag, O. (2017). Silencing linguistic diversity: The extent, the determinants and consequences of the monolingual beliefs of Flemish teachers. International Journal of Bilingual Education and Bilingualism, 20, 542556. doi.org/10.1080/13670050.2015.1102860

Rumsey, B. (2018). The sociocultural dynamics of indigenous multilingualism in northwestern Australia. Language and Communication, 62, 91-101. doi.org/10.1016/j.langcom.2018.04.011

Schissel J.L., De Korne H., \& López-Gopar, M. (2018). Grappling with translanguaging for teaching and assessment in culturally and linguistically diverse contexts: Teacher perspectives from Oaxaca, Mexico. International Journal of Bilingual Education and Bilingualism. 10.1080/13670050.2018.1463965

Shohamy, E. G. (2006). Language policy: Hidden agendas and new approaches. London: Routledge.

Simons, G.F., \& Lewis M. (2013). The world's languages in crisis. In E. Mihas, B. Perley, G. Rei-Doval, \& K. Wheatley (Eds.), Responses to language endangerment: In honor of Mickey Noonan. New directions in language documentation and language revitalization (pp. 3-20). Amsterdam: John Benjamins. 
Swain, M., \& Lapkin, S. (2005). The evolving sociopolitical context of immersion education in Canada: Some implications for program development. International Journal of Applied Linguistics, 15, 169-186.

Tovey, J., \& McNeilage, A. (2013, October 3). Number of HSC language students falls to record low. Sydney Morning Herald. www.smh.com.au/education/ number-of-hsc-language-students-falls-to-record-low-20131002-2usv2. html

Truscott, A., \& Malcolm, I. (2010). Closing the policy-practice gap: Making Indigenous language policy more than empty rhetoric. In J. Hobson, K. Lowe, S.>Poetsch \& M. Walsh (Eds.), Re-awakening languages: Theory and practice in the revitalisation of Australia's Indigenous languages (pp. 6-21). Sydney: Sydney University Press.

Turner, M., \& Cross, R. (2016). Making space for multilingualism in Australian schooling. Language and Education, 30, 289-297.

Van Der Walt, C., \& Klapwijk, N. (2015). Language of learning and teaching in a multilingual school environment: What do teachers think? Language Matters, 46, 293-318.

Van Der Wildt, A., Van Houtte, M., \& Van Avermaet, P. (2017). Opening up towards children's languages: Enhancing teachers' tolerant practices towards multilingualism. School Effectiveness and School Improvement, 28, 136-152. doi.org/10.1080/09243453.2016.1252406

Vertovec, S. (2007). Super-diversity and its implications. Ethnic and Racial Studies, 30, 1024-1054.

Weinmann, M., \& Arber, R. (2016, November 21). This is what we need to do to boost languages learning in Australian schools [Blog]. AARE EduResearch Matters. www. aare.edu. $\mathrm{au} / \mathrm{blog} / \mathrm{p}=1872$

Weinmann, M., \& Arber, R. (2017). Orientating multilingualism: Navigating languages teacher identities. Curriculum Perspectives, 37, 173-179. doi.org/10.1007/s41297-017-0028-4

Young, A.S. (2014). Unpacking teachers' language ideologies: Attitudes, beliefs, and practiced language policies in schools in Alsace, France. Language Awareness, 23, 157-171. doi.org/10.1080/09658416.2013.863902

Young, A.S. (2017). "Non, moi je lui dis pas en Turc, ou en Portugais, ou en, j'sais pas moi en Arabe": Exploring teacher ideologies in multilingual/cultural preschool contexts in France. Bellaterra Journal of Teaching \& Learning Language \& Literature, 10. doi.org/10.5565/rev/jt13.729 